\title{
Results of the Palaeomagnetic Research on Rocks of Pre-Cambrian and Lower Palaeozoic Age in Czechoslovakia.
}

\author{
Václav BuchA \\ Geophysical Institute of the Czechoslovakian Academy of Science, Prague., Czechoslovakia
}

\section{Introduction}

So far palaeomagnetic observations on rocks of Pre-Cambrian, Cambrian and Ordovician age in comparison with younger geological periods show a relatively large scatter and nonsystematic pole positions computed from the mean directions. One of the main reasons may be the insufficiency of the material which has been investigated. In consequence the duration of the Cambrian and Ordovician epochs (approximately 160 milions years) are poorly represented in palaeomagnetic literature.

For this reason a systematic investigation on a relatively large number of rock-samples from these epochs was undertaken in Czechoslovakia with the aim of amplifying the polar wandering curve for all the main stages of the Cambrian and Ordovician.

More than 1000 rock-samples from 60 localities have been collected and each geological stage is represented. Thus the chronological succession and the possibility of successive time correlation of palaeomagnetic results with the rocks of the corresponding age is possible. The rock-samples have been subject to laboratory stability tests by demagnetization in a.c. fields of $1000 \mathrm{Oe}$, in d.c. fields, by heating and their mineralogical composition was investigated. Some new palaeomagnetic results of upper Proterozoic-Eocambrian rocks are added.

\section{Geology}

A mighty formation of rocks appearing above the spilite Proterozoic in Central Bohemia is geologicolly considered to be Eocambrian. Unmetamorphosed layers are formed by clay and aleuritic slates and graywackes.

The Bohemian older Palaeozoic rocks may be divided into two sedimentary cycles i.e. an older, Cambrian cycle and a younger Ordovician-Silurian-Devonian cycle. Cambrian and Ordovician rocks cover a wide area; of the Silurian and Devonian rocks only small denuded relicts remain. The deposits of middle-Cambrian age are reliably palaeontologically dated as Acadian, in which zone Jince-beds may be included. The question of how much of the lower Cambrian is present remains open. The upper-Cambrian rocks are represented by strongly developed porphyre and porphyrite eruptions.

The total known thickness of Cambrian rocks in Barrandian region amounts to roughly $3000 \mathrm{~m}$. The oldest horizons resting on Proterozoic beds are the grey green coloured Žitec conglomerates which have the thickness of $100 \mathrm{~m}$. They are followed by about $600 \mathrm{~m}$ of the 
red or pink coloured Hluboš-conglomerates. Above them the Sadek-beds, red brown and grey-green in colour, occur (thickness $600 \mathrm{~m}$ ). The succeeding beds are made up of the flinty Holšín conglomerates and Hořice beds. The dominant facies, however, are the Bohutínsandstones, dark grey or somewhat red coloured. The only fossiliferous members of the Czech Cambrian rocks are the Jince beds divided into a lower and an upper horizont. They are classified as of middle-Cambrian age (Paradoxides). They mostly occur as grey-green sandstones with the intercalated red slate horizons.

During the intense volcanic activity in the upper Cambrian the two great belts of eruptive rocks developed, i.e. Krivoklát-Rokycany and Strašice belts in which repeated effusions of porphyres and porphyrites with tuffits are found. The volcanic activity continued in some places into the lower Ordovician.

All the stages of the Ordovician from Tremadocian to Ashgillian are found in the Barrandian. In the lower Ordovician the Tremadocian comprises the Krušná hora beds divided into Třenice beds-red-brown or grey-green arkoses-and Mílina beds mainly represented by red slates. The Klabava beds belong to Skiddavian. In their lower part a brick red slates facies and graywackes are developed. The Llanvirnian is represented by Šárka-beds. Close to the ancient coast the facies with the iron-ore is found and here the Šárka beds are formed of haematite ores.

The middle Ordovician (Llandeilian) is represented by the Dobrotivá, Libeň and Letná beds followed by Drabov-flints.

In the upper Ordovician (Caradocian and Ashgillian) the Černín-layers in which haematite ores are developed in the North-west, are followed by the clay slates of the Chlustina beds and the Bohdalec beds. The youngest horizont of the Ordovician epoch-the Ashgillianis represented by the Králův dvưrůslates, and Kosov beds.

\section{Procedure}

The directions of magnetization were measured on a sensitive astatic magnetometer housed at the Prühonice laboratory. Apart from the volcanics and the ores, the rocks investigated have a low intensity of natural remanent magnetization of the order of $10^{-5}$ to $10^{-7}$ CGSM. In some cases the intensity was even lower and in such groups of rocks the scatter of measurements showed them to be unsuitable.

In the remaining rocks stability of magnetization was tested mainly in two ways. In a few cases, noted in the description of results, Graham's fold test was possible. However it is rarely possible to be sure that exactly the same bed has been sampled on opposite limbs of a fold, so that the test in some cases is merely one of discordance of dip.

The main test of magnetic stability and of magnetic cleaning was that of a.c. demagnetization about three perpendicular axes. Three to five samples from each locality (where 10-15 samples were usually collected) were progressivey demagnetized in fields of up to 1000 Oe (Bucha, 1962, 1963).

When the direction of the demagnetized samples did not differ significantly from the mean of the untreated samples, the untreated samples were not demagnetized and the rocks 
from those sets were regarded as stable. Where the difference was significant such localities were not considered further in this study. (These amounted to about 12 out of the 60 localities visited).

The present investigation was concerned with the relation of the declination and inclination measured to the age of the rocks, using as a conveninent method of comparison the "polar wandering" curves in the sense normally adopted in palaeomagnetism.

\section{Results}

New preliminary results for the upper Proterozoic-Eocambrian epoch are given in Fig. 1. (Tab. 1) Some of these rocks in which only stable magnetization was found by means of a.c. demagnetization form closed groups. On the other hand, groups which show a certain unstable component of magnetization are more scattered.

Table 1. Proterozoic-Eocambrian Palaeomagnetic Data Geographical Coordinates of All Localities $\varphi=$ $50^{\circ}, \lambda=14^{\circ}$

\begin{tabular}{l|c|c|c|c|c|c|c|c|c}
\hline \multirow{2}{*}{ No. } & \multirow{2}{*}{$\begin{array}{c}\text { No. } \\
\text { Spec }\end{array}$} & \multicolumn{4}{|c|}{ Magnetic Direction } & \multicolumn{5}{|c}{ Pole Position } \\
\cline { 3 - 10 } & & Decl. & Incl. & $\alpha$ & $R$ & Lat. & Long. & $p$ & $m$ \\
\hline 1 & 8 & $308^{\circ}$ & $32^{\circ}$ & $4^{\circ}$ & 7 & $37^{\circ}$ & $265^{\circ}$ & 3 & 3 \\
2 & 3 & $310^{\circ}$ & $21^{\circ}$ & $9^{\circ}$ & 3 & $34^{\circ}$ & $259^{\circ}$ & 5 & 5 \\
3 & 3 & $340^{\circ}$ & $-25^{\circ}$ & $19^{\circ}$ & 3 & $24^{\circ}$ & $215^{\circ}$ & 11 & 10 \\
& & $319^{\circ}$ & $9^{\circ}$ & & & $32^{\circ}$ & $239^{\circ}$ & & \\
4 & 8 & $149^{\circ}$ & $7^{\circ}$ & $14^{\circ}$ & 8 & $30^{\circ}$ & $230^{\circ}$ & 7 & 7 \\
5 & 6 & $106^{\circ}$ & $4^{\circ}$ & $15^{\circ}$ & 6 & $8^{\circ}$ & $270^{\circ}$ & 7 & 7 \\
6 & 5 & $133^{\circ}$ & $65^{\circ}$ & $19^{\circ}$ & 4 & $-14^{\circ}$ & $225^{\circ}$ & 25 & 15 \\
7 & 9 & $137^{\circ}$ & $16^{\circ}$ & $27^{\circ}$ & 6 & $14^{\circ}$ & $223^{\circ}$ & 19 & 16 \\
& & $131^{\circ}$ & $23^{\circ}$ & & & $9^{\circ}$ & $237^{\circ}$ & & \\
\hline
\end{tabular}
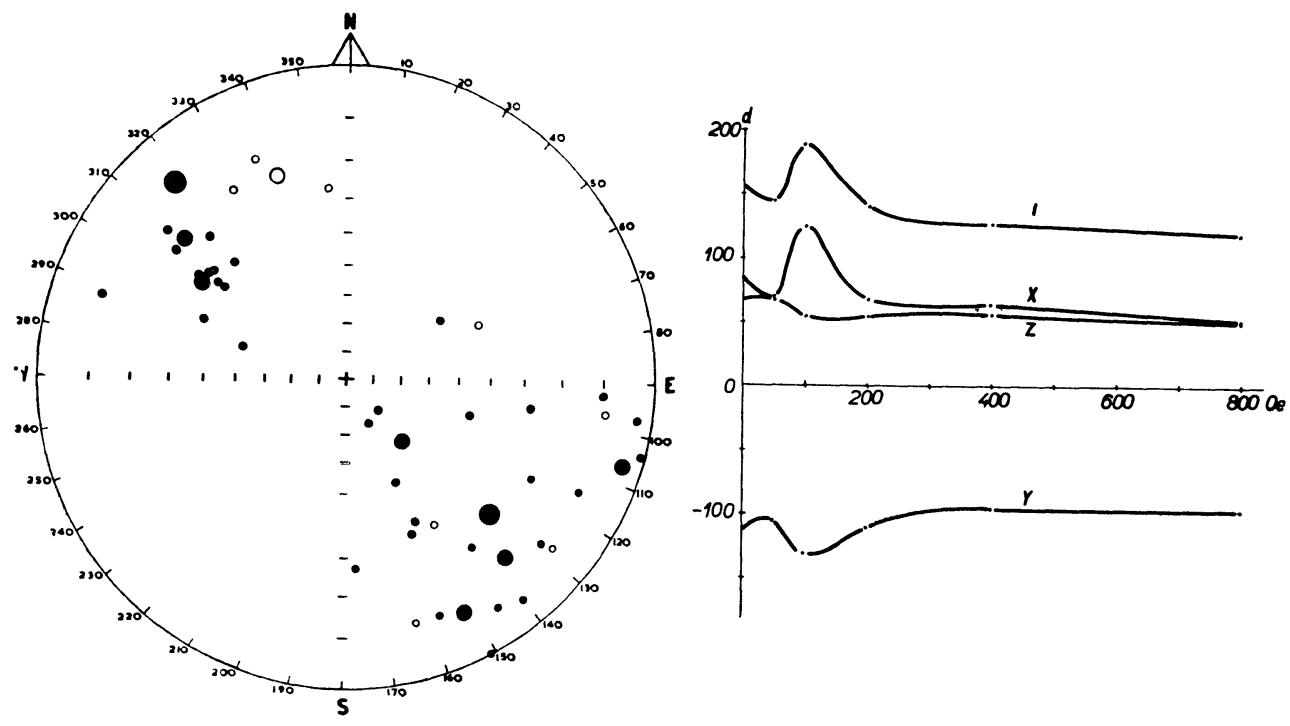

Fig. 1 
The Cambrian epoch has been divided into four chronologically different groups. The oldest Hluboš beds studied, (1st group) showed a low intensity of N.R.M. but the measurements were consistent, the scatter small, and the rocks appeared to be magnetically stable. A large number of samples have been collected from the Sadek-beds horizont (2nd group). The stereogram (Fig. 2) shows, in the same way as some other Lower Palaeozoic groups of rocks, a certain scatter which may be due to the fact that magnetite and haematite grains in the rock have been imperfectly oriented during a relatively rapid deposition and to the secular variation. However in view of the large number of measurements and with regard to their palaeomagnetic stability (both a.c.demagnetization and fold test) the results may be regarded as representing this geological member. The results of the fold test together with a.c. demagnetization are given on Fig. 3. (Tab. 2).

In the third group, the measurements particularly from the Jince beds regarded on
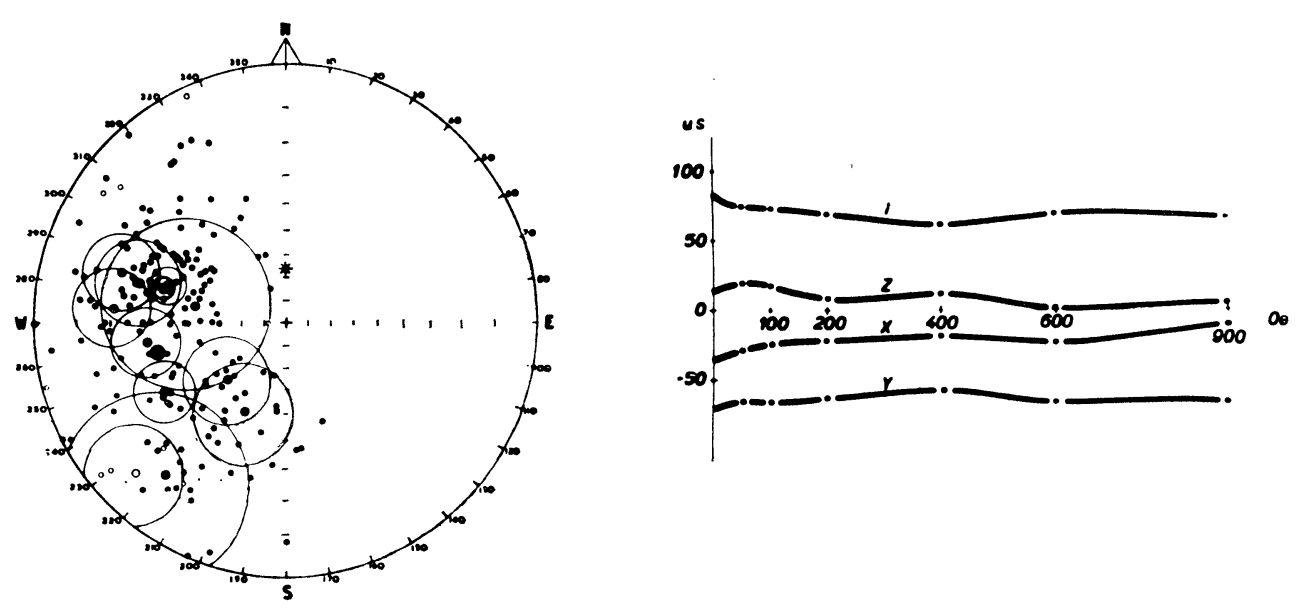

Fig. 2
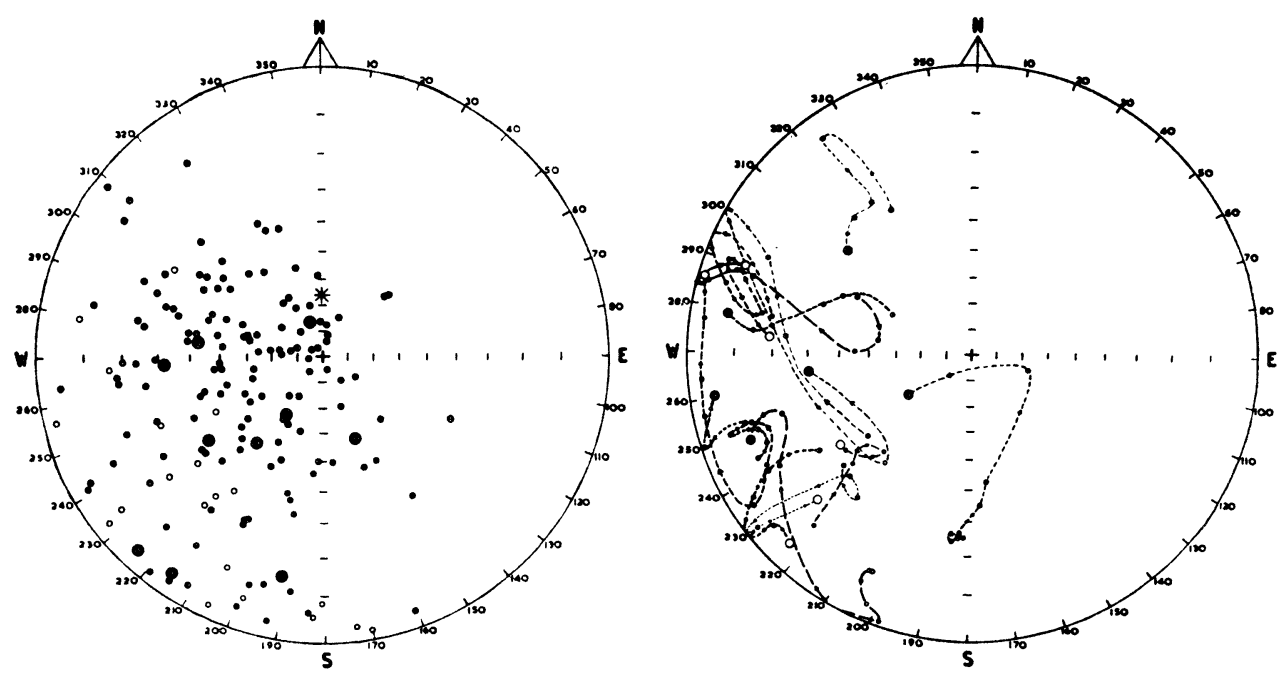

Fig. 3 
Table 2. Cambrian, Ordovician and Silurian Palaeomagnetic Data. Geographical Coordinates of All Localities $\varphi=50^{\circ}, \lambda=14^{\circ}$

\begin{tabular}{|c|c|c|c|c|c|c|c|c|c|c|}
\hline \multirow{2}{*}{ Rocks Sampled } & \multirow{2}{*}{ No. } & \multirow{2}{*}{$\begin{array}{l}\text { No. } \\
\text { Spec }\end{array}$} & \multicolumn{4}{|c|}{ Magnetic Direction } & \multicolumn{4}{|c|}{ Pole Position } \\
\hline & & & Decl. & Incl. & $\alpha$ & $R$ & Lat. & Long. & $p$ & $m$ \\
\hline \multirow[t]{2}{*}{ Lower Cambrian I. } & 1 & 18 & $289^{\circ}$ & $44^{\circ}$ & $10^{\circ}$ & 17 & $31^{\circ}$ & $288^{\circ}$ & 8 & 6 \\
\hline & 2 & 16 & $\begin{array}{l}287^{\circ} \\
288^{\circ}\end{array}$ & $\begin{array}{l}12^{\circ} \\
28^{\circ}\end{array}$ & $11^{\circ}$ & 15 & $\begin{array}{l}16^{\circ} \\
23^{\circ}\end{array}$ & $\begin{array}{l}275^{\circ} \\
280^{\circ}\end{array}$ & 6 & 6 \\
\hline \multirow[t]{13}{*}{ Lower Cambrian II. } & 3 & 56 & $288^{\circ}$ & $38^{\circ}$ & $7^{\circ}$ & 49 & $27^{\circ}$ & $285^{\circ}$ & 5 & 4 \\
\hline & 4 & 21 & $276^{\circ}$ & $21^{\circ}$ & $12^{\circ}$ & 18 & $12^{\circ}$ & $297^{\circ}$ & 6 & 6 \\
\hline & 5 & 13 & $287^{\circ}$ & $23^{\circ}$ & $12^{\circ}$ & 10 & $20^{\circ}$ & $279^{\circ}$ & 6 & 6 \\
\hline & 6 & 20 & $286^{\circ}$ & $28^{\circ}$ & $14^{\circ}$ & 17 & $22^{\circ}$ & $282^{\circ}$ & 8 & 8 \\
\hline & 7 & 7 & $280^{\circ}$ & $49^{\circ}$ & $32^{\circ}$ & 5 & $29^{\circ}$ & $298^{\circ}$ & 28 & 21 \\
\hline & 8 & 11 & $206^{\circ}$ & $47^{\circ}$ & $20^{\circ}$ & 9 & $-8^{\circ}$ & $351^{\circ}$ & 16 & 13 \\
\hline & 9 & 12 & $219^{\circ}$ & $14^{\circ}$ & $25^{\circ}$ & 8 & $-24^{\circ}$ & $331^{\circ}$ & 13 & 13 \\
\hline & 10 & 9 & $226^{\circ}$ & $-10^{\circ}$ & $13^{\circ}$ & 9 & $-31^{\circ}$ & $317^{\circ}$ & 7 & 6 \\
\hline & 11 & 8 & $229^{\circ}$ & $53^{\circ}$ & $18^{\circ}$ & 7 & $4^{\circ}$ & $325^{\circ}$ & 17 & 12 \\
\hline & 12 & 13 & $240^{\circ}$ & $31^{\circ}$ & $11^{\circ}$ & 12 & $-18^{\circ}$ & $314^{\circ}$ & 7 & 6 \\
\hline & 13 & 14 & $264^{\circ}$ & $32^{\circ}$ & $12^{\circ}$ & 13 & $9^{\circ}$ & $300^{\circ}$ & 7 & 7 \\
\hline & 14 & 7 & $287^{\circ}$ & $36^{\circ}$ & $4^{\circ}$ & 7 & $26^{\circ}$ & $285^{\circ}$ & 2 & 2 \\
\hline & & & $257^{\circ}$ & $34^{\circ}$ & & & $6^{\circ}$ & $305^{\circ}$ & & \\
\hline \multirow[t]{7}{*}{ Middle-Cambrian } & 15 & 18 & $59^{\circ}$ & $-16^{\circ}$ & $12^{\circ}$ & 16 & $13^{\circ}$ & $135^{\circ}$ & 6 & 6 \\
\hline & 16 & 12 & $26^{\circ}$ & $17^{\circ}$ & $14^{\circ}$ & 11 & $44^{\circ}$ & $157^{\circ}$ & 7 & 7 \\
\hline & 17 & 14 & $53^{\circ}$ & $-48^{\circ}$ & $18^{\circ}$ & 11 & $-2^{\circ}$ & $150^{\circ}$ & 15 & 11 \\
\hline & & & $45^{\circ}$ & $-16^{\circ}$ & & & $20^{\circ}$ & $146^{\circ}$ & & \\
\hline & 18 & 12 & $203^{\circ}$ & $9^{\circ}$ & $18^{\circ}$ & 10 & $-32^{\circ}$ & $347^{\circ}$ & 9 & 9 \\
\hline & 19 & 10 & $243^{\circ}$ & $46^{\circ}$ & $12^{\circ}$ & 9 & $5^{\circ}$ & $321^{\circ}$ & 10 & 8 \\
\hline & & & $220^{\circ}$ & $29^{\circ}$ & & & $-16^{\circ}$ & $334^{\circ}$ & & \\
\hline \multirow[t]{9}{*}{ Upper Cambrian } & 20 & 19 & $189^{\circ}$ & $32^{\circ}$ & $21^{\circ}$ & 12 & $-22^{\circ}$ & $4^{\circ}$ & 14 & 12 \\
\hline & 21 & 41 & $192^{\circ}$ & $66^{\circ}$ & $10^{\circ}$ & 34 & $9^{\circ}$ & $6^{\circ}$ & 13 & 8 \\
\hline & 22 & 18 & $152^{\circ}$ & $-41^{\circ}$ & $12^{\circ}$ & 16 & $-55^{\circ}$ & $61^{\circ}$ & 9 & 7 \\
\hline & 23 & 18 & $208^{\circ}$ & $-12^{\circ}$ & $15^{\circ}$ & 15 & $-40^{\circ}$ & $336^{\circ}$ & 8 & 8 \\
\hline & 24 & 7 & $169^{\circ}$ & $-24^{\circ}$ & $15^{\circ}$ & 7 & $-52^{\circ}$ & $32^{\circ}$ & 9 & 8 \\
\hline & 25 & 5 & $179^{\circ}$ & $-5^{\circ}$ & $34^{\circ}$ & 4 & $-43^{\circ}$ & $15^{\circ}$ & 17 & 17 \\
\hline & 26 & 8 & $179^{\circ}$ & $62^{\circ}$ & $22^{\circ}$ & 7 & $3^{\circ}$ & $15^{\circ}$ & 26 & 17 \\
\hline & 27 & 6 & $177^{\circ}$ & $14^{\circ}$ & $18^{\circ}$ & 6 & $-33^{\circ}$ & $17^{\circ}$ & 9 & 9 \\
\hline & & & $181^{\circ}$ & $11^{\circ}$ & & & $-34^{\circ}$ & $13^{\circ}$ & & \\
\hline \multirow[t]{13}{*}{ Lower Ordovician } & 28 & 30 & $106^{\circ}$ & $49^{\circ}$ & $12^{\circ}$ & 24 & $13^{\circ}$ & $72^{\circ}$ & 11 & 8 \\
\hline & 29 & 10 & $141^{\circ}$ & $29^{\circ}$ & $4^{\circ}$ & 9 & $-17^{\circ}$ & $53^{\circ}$ & 3 & 2 \\
\hline & 30 & 7 & $142^{\circ}$ & $65^{\circ}$ & $6^{\circ}$ & 7 & $12^{\circ}$ & $40^{\circ}$ & 7 & 4 \\
\hline & 31 & 5 & $206^{\circ}$ & $46^{\circ}$ & $18^{\circ}$ & 5 & $-10^{\circ}$ & $322^{\circ}$ & 14 & 11 \\
\hline & 32 & 9 & $98^{\circ}$ & $49^{\circ}$ & $12^{\circ}$ & 9 & $17^{\circ}$ & $78^{\circ}$ & 11 & 8 \\
\hline & 33 & 19 & $174^{\circ}$ & $35^{\circ}$ & $13^{\circ}$ & 16 & $-20^{\circ}$ & $20^{\circ}$ & 8 & 7 \\
\hline & 34 & 21 & $112^{\circ}$ & $42^{\circ}$ & $14^{\circ}$ & 17 & $6^{\circ}$ & $72^{\circ}$ & 11 & 9 \\
\hline & 35 & 29 & $279^{\circ}$ & $-55^{\circ}$ & $11^{\circ}$ & 24 & $21^{\circ}$ & $74^{\circ}$ & 11 & 8 \\
\hline & 36 & 9 & $109^{\circ}$ & $66^{\circ}$ & $10^{\circ}$ & 9 & $26^{\circ}$ & $58^{\circ}$ & 14 & 8 \\
\hline & 37 & 16 & $120^{\circ}$ & $67^{\circ}$ & $7^{\circ}$ & 15 & $22^{\circ}$ & $52^{\circ}$ & 9 & 6 \\
\hline & 38 & 5 & $124^{\circ}$ & $72^{\circ}$ & $13^{\circ}$ & 5 & $27^{\circ}$ & $44^{\circ}$ & 23 & 23 \\
\hline & 39 & 9 & $170^{\circ}$ & $75^{\circ}$ & $21^{\circ}$ & 9 & $22^{\circ}$ & $19^{\circ}$ & 35 & 19 \\
\hline & & & $140^{\circ}$ & $60^{\circ}$ & & & $8^{\circ}$ & $43^{\circ}$ & & \\
\hline \multirow[t]{8}{*}{ Upper Ordovician } & 40 & 10 & $50^{\circ}$ & $55^{\circ}$ & $14^{\circ}$ & 9 & $52^{\circ}$ & $107^{\circ}$ & 14 & 10 \\
\hline & 41 & 11 & $134^{\circ}$ & $53^{\circ}$ & $20^{\circ}$ & 9 & $3^{\circ}$ & $51^{\circ}$ & 19 & 14 \\
\hline & 42 & 9 & $103^{\circ}$ & $46^{\circ}$ & $20^{\circ}$ & 8 & $13^{\circ}$ & $77^{\circ}$ & 16 & 12 \\
\hline & 43 & 11 & $129^{\circ}$ & $43^{\circ}$ & $16^{\circ}$ & 10 & $-2^{\circ}$ & $59^{\circ}$ & 12 & 10 \\
\hline & 44 & 13 & $120^{\circ}$ & $22^{\circ}$ & $23^{\circ}$ & 10 & $-9^{\circ}$ & $74^{\circ}$ & 13 & 12 \\
\hline & 45 & 9 & $83^{\circ}$ & $71^{\circ}$ & $10^{\circ}$ & 9 & $42^{\circ}$ & $64^{\circ}$ & 15 & 9 \\
\hline & 46 & 8 & $31^{\circ}$ & $61^{\circ}$ & $16^{\circ}$ & 7 & $67^{\circ}$ & $112^{\circ}$ & 18 & 12 \\
\hline & & & $102^{\circ}$ & $55^{\circ}$ & & & $20^{\circ}$ & $72^{\circ}$ & & \\
\hline Silurian & 47 & 25 & $232^{\circ}$ & $-9^{\circ}$ & $6^{\circ}$ & 23 & $27^{\circ}$ & $133^{\circ}$ & 3 & 3 \\
\hline
\end{tabular}


palaeolontological grounds as middle Cambrian age are given. Reversed magnetization has been found in some groups of samples. The mean values of this group compared with the older group of Sádek beds show a diminuation in the values of declination and inclination; the magnetization directions are rotated anticlockwise with respect to the older beds. The results are given on Fig. 4.

The measurements on the youngest Cambrian rocks particularly the porphyrites and porphyres belong to the 4 th group of upper Cambrian age. The mean values of $D$ and $I$ are very close to the data which Creer, Irving and Runcorn (1954) give for the upper Cambrian. A plot of the results together with the demagnegtization curves is given in Fig. 5. The relatively high scatter in the values of inclination could be due to unstability of the remanent magnetization; but the demagnetization curves both for eruptive and for sedimentary rocks of
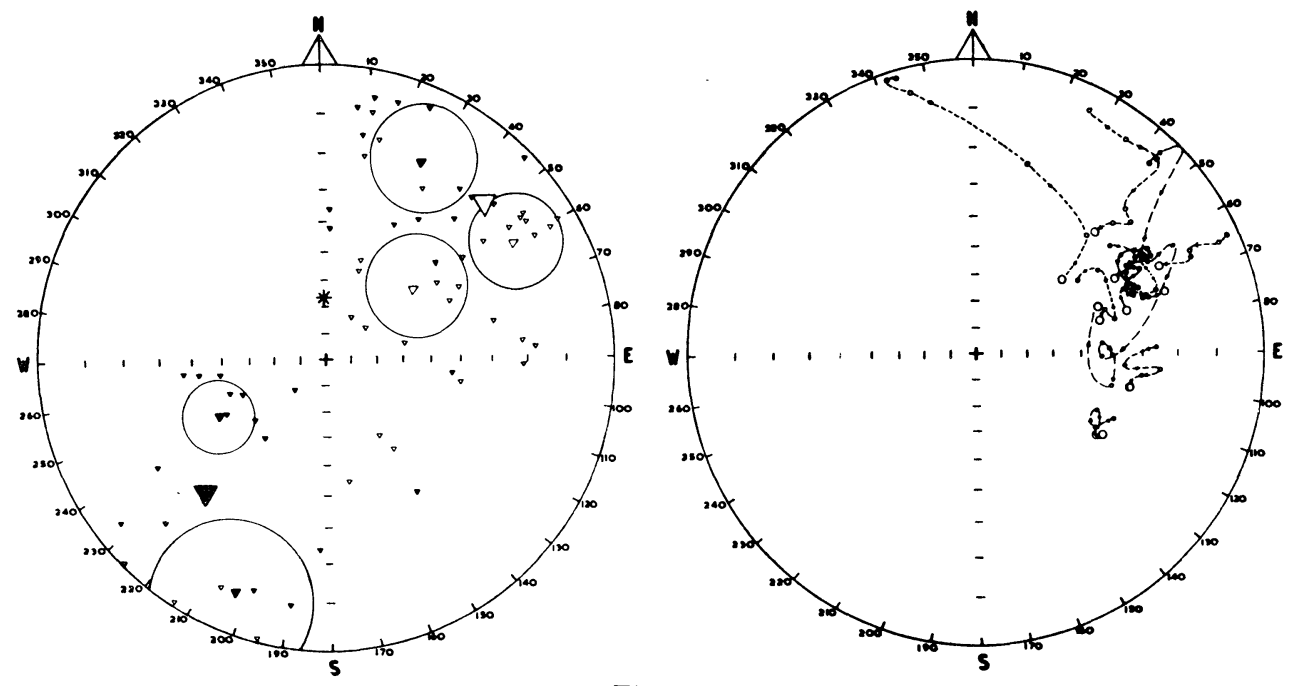

Fig. 4
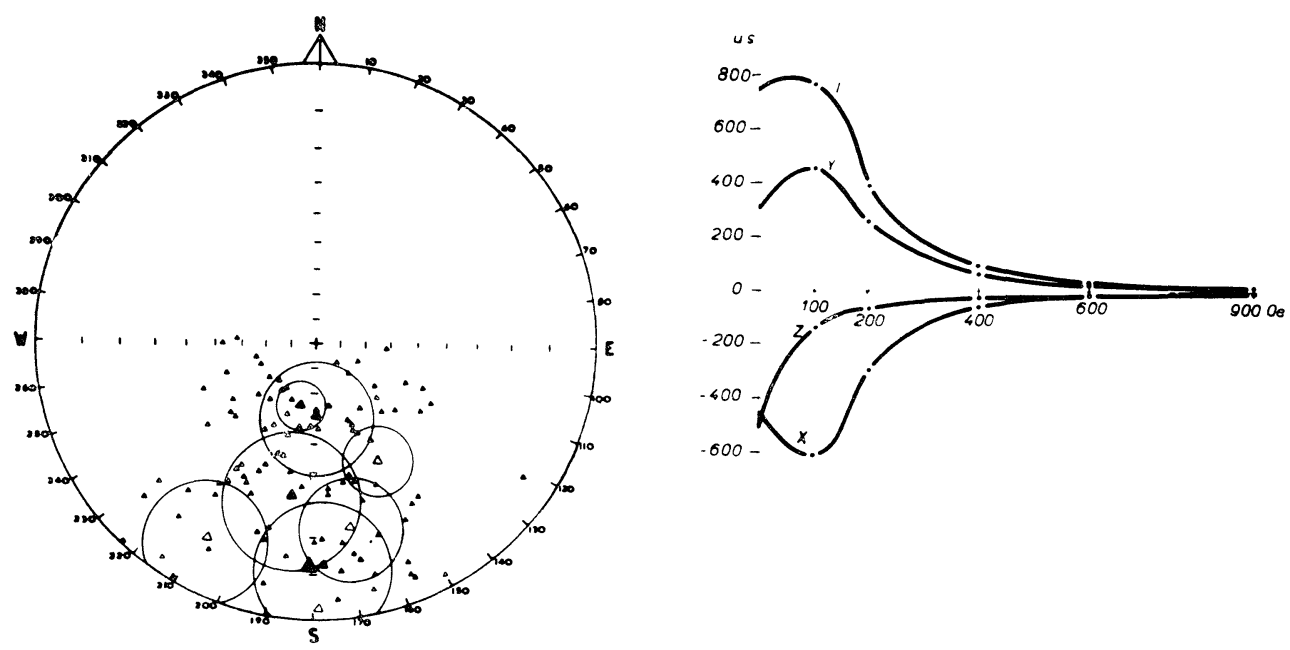

Fig. 5 
this group suggest that the cause of the spread seems to be the change of the past earth's magnetic field.

Rock-samples of lower and upper Ordovician age have also been investigated. The rocks of middle Ordovician age were very weakly magnetized and were unstable.

The 5 th group of measurements, rocks of lower Ordovician age, were made on redcoloured sedimentary rocks, ores and some diabases. The distribution of individual values is shown in the stereogram (Fig. 6.) along with their typical demagnetization curves. The results of the fold test together with a.c. demagnetization are given on Fig. 7 .

The 6th group of measurements on rocks of upper Ordovician age, were obtained from brown-coloured rocks and samples of chamosite ores. The results (Fig. 8.) show a relatively tight grouping of the mean values for the collection investigated. The mean direction of magnetization is consistent with the anticlockwise trend discerned in the earlier horizons.
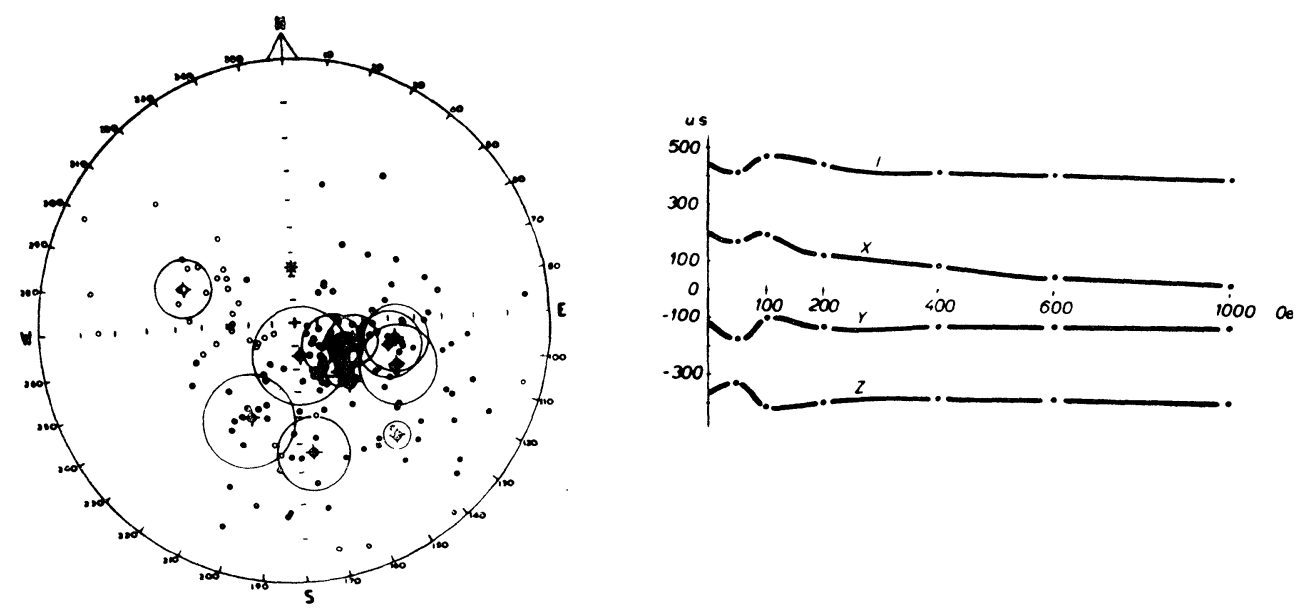

Fig. 6
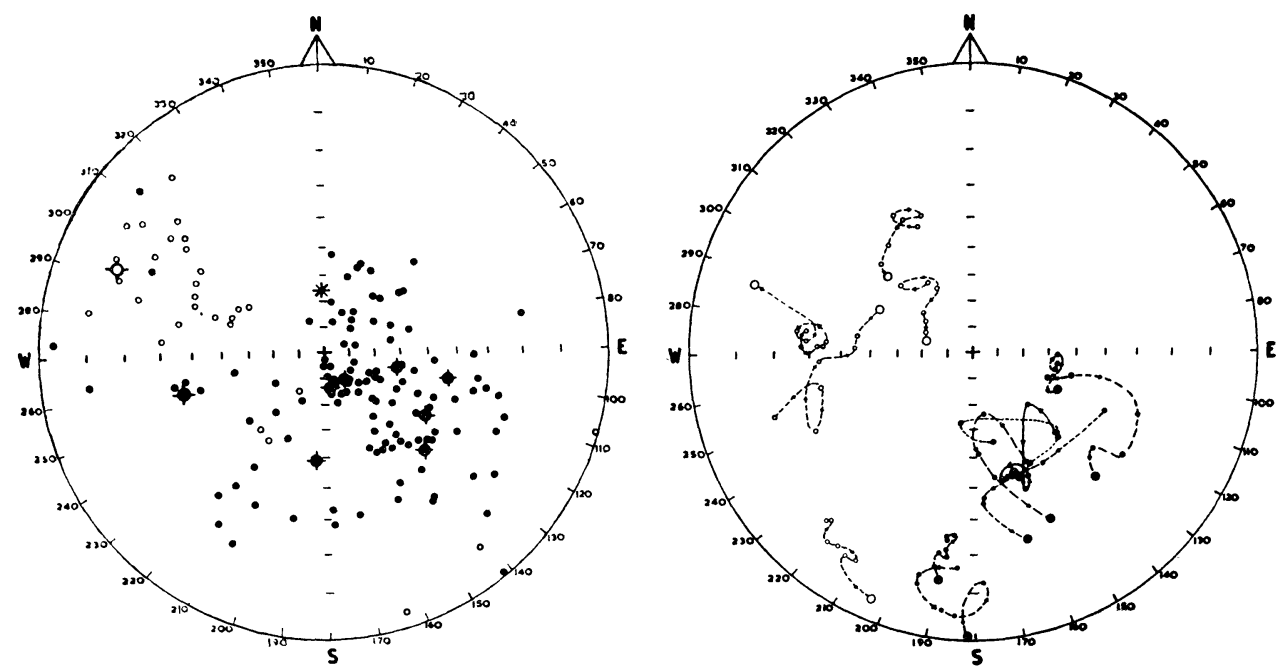

Fig. 7 
Black diabases of Silurian age show a relatively strong reverse magnetization and form a closed group in the stereogram (Fig. 9.).
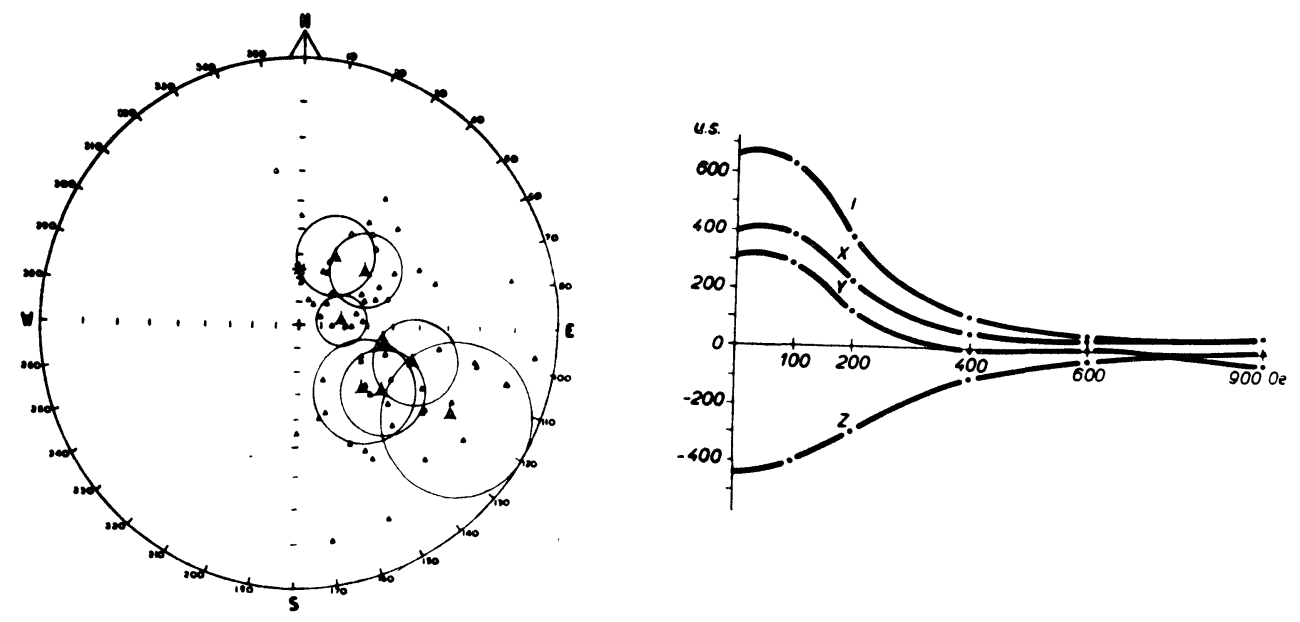

Fig. 8
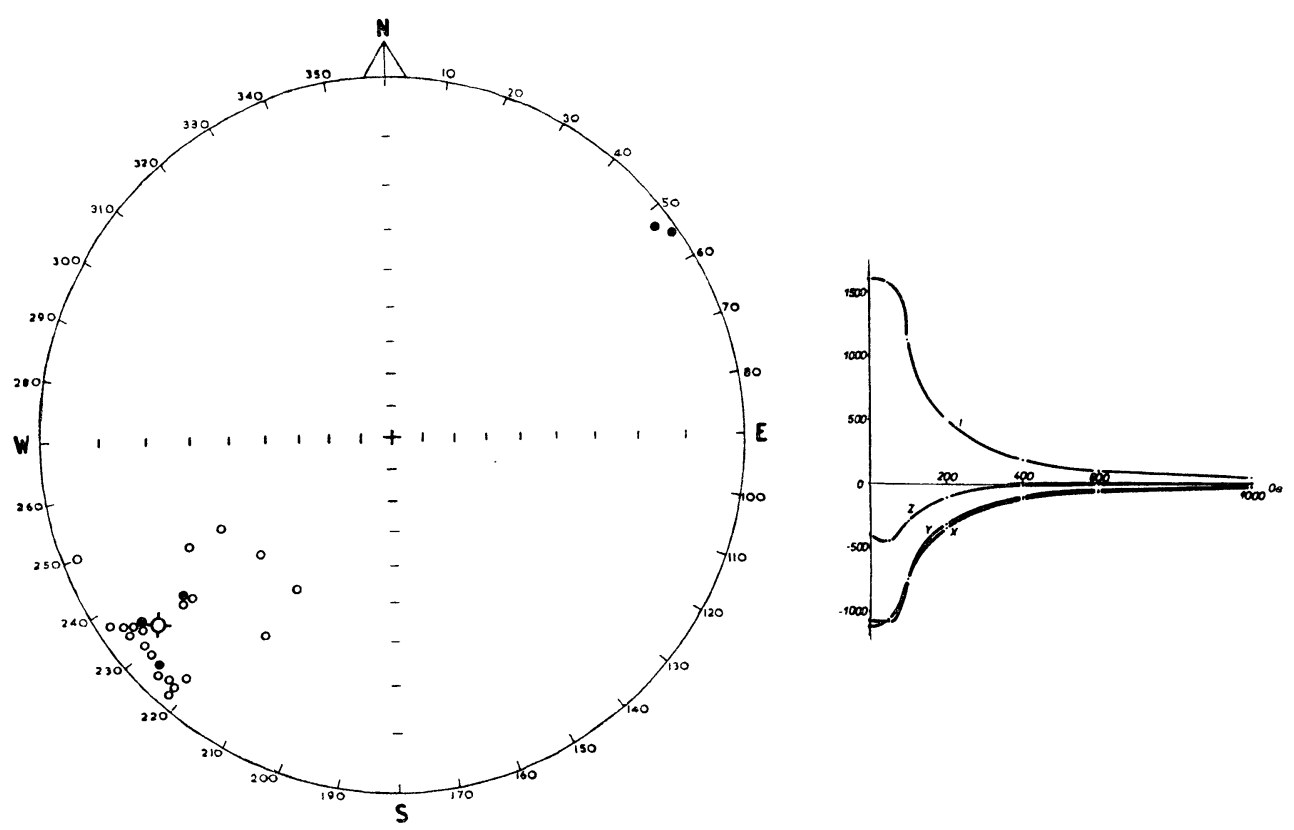

Fig. 9

\section{Discussion of results}

Certain conclusion can be drawn from the chronological succession of values of $D$ and $I$. As the rocks are unmetamorphosed it is reasonable to assume the remanent magnetization is original. This was found also petrographically. Figure 10 shows the computed pole positions which satisfy these measurements. If we consider the antipoles for our Cambrian and Ordovician results with regard to those that are usually taken and it is assumed that the scatter 


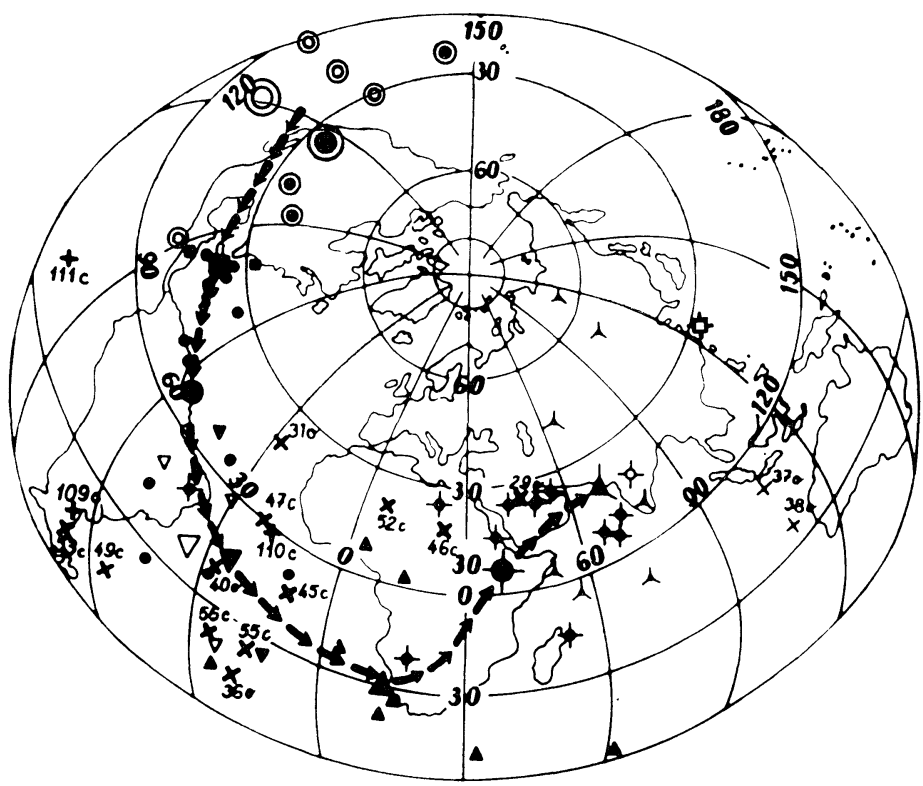

Fig. 10

of values corresponds to more intense changes of the geomagnetic field, then the chronological succession of the pole positions forms a "polar-wandering" curve whose direction is unambigous,-from west to east from the region of North and Central America through Africa in relatively low latitudes, that is in the opposite sense to the "polar-wandering" curves commonly described in the literature. Proterozoic-Eocambrian (double circles), lower Cambrian (squares and circles), middle Cambrian (converted triangles), upper Cambrian (triangles), lower Ordovician (circles -), upper Ordovician (triangles ), Silurian $中$. On geological grounds the interpretation of the succession of pole positions cannot be attributed to rotational movements, of the territory investigated for the evidence is only of vertical movement.

Whatever the interpretation of the motion involved whether as polar wandering, continental drift or some combination of the two, the velocity of the movement would be relatively higher $\left(15^{\circ}\right.$ for 20 million years) for these periods than has formerly been supposed. On the basis of direction the transition from early Palaeozoic to late Palaeozoic and early Mesozoic is much easier to understand. Some consideration must be given to the difference in the direction of the present "polar wandering" curve and those previously published. The earlier results are discussed and tabulated by Cox and Doell (1960) and by Irving. The pole positions, plotted in the Pacific region are widely scattered and difficult to interpret. If, however, the antipoles are considered and it is assumed that the scatter of values corresponds to more intense changes of the geomagnetic field then the European and American results form a more homogeneous group and fit the longer "polar wandering" path here presented. The results published by Howell and Martinez (1957) (47C and 49C in Cox and Doell 1960) are in agreement with this and so is a result $46 \mathrm{C}$. The pole position $53 \mathrm{C}$ which 
though stated by Collinson and Runcorn (1960) to be Mississipian is known on faunal grounds to be Cambrian (Cox and Doell, 1960). So too does the antipole of the Welsh Cambrian results of Creer (45C-Creer and al, 1957), and Irving's Cambrian results from Australia (55c, 56c) (Irving and Green, 1958). The same is valid for the Russian Cambrian results (Kalašnikov, 1961) (109c, 110c, 111c in Fig. 10). In general, if the geological subdivision of Cambrian rocks examined is known more precisely, it will be possible to carry out a more detailed interpretation of them.

The earlier Ordovician results (Cox and Doell, 1960), which are very rare, show a great spread (29o, 31o, 36o, 37o, 38o, 40o). Though some of them agree with our results, a more systematic study is necessary in all continets. Our Silurian pole position agrees very well with the American, British and Russian data; the same do our data for younger periods (Bucha, 1962, 1963).

\section{References}

Bucha, V., Palaeomagnetic characteristics of some rocks of Precambrian and Palaeozoic age in Czechoslovakia and their magnetic stability: Travaux de l'Inst. Géophys. de l'Acad. Tchécosl. Sci., No. 157, 1962.

Bucha, V., Dynamics of the earth's magnetic field: Travaux de l'Inst. Géophys. de l'Acad. Tchécosl. Sci., No $170,1963$.

Collinson, D.W., ard Runcorn, S.K., Further paleomagnetic observations in North America: Geol. Soc. America Bull., v. 71, 1960.

Cox, A., Doell, R.R., Review of paleomagnetism : Geol. Soc. America Bull., V. 71, p. 645-768, 1960.

Creer, K.M., Irving, E., and Runcorn, S.K., Palaeomagnetic investigations in Great Britain VI, Geophysical interpretation of palaeomagnetic directions from Great Britain: Royal Soc. London Philos. Trans., ser. A, v. 250, p. 144-156, 1957.

Howell, L.G., and Martinez, J.D., Polar movement as indicated by rock magnetism : Geophysics, v. 22, p. 384-397, 1957.

Irving, E., and Green, R., Polar movement relative to Australia: Royal Astron. Soc. Geophys. Jour., v. 1, p. 64-72, 1958.

Kalašnikov, A., Istorija geomagnitnogo polja: Izv. AN SSSR, s. geofiz. 9, p. 1243, 1961. 